\title{
Characteristic Features of Occupational Health Service in Japan
}

\author{
-Towards a Future Cooperative Program with Other, Especially Asian, Countries-
}

\author{
Kenzaburo TsuchIYA \\ President, University of Occupational and Environmental Health, Japan. Kitakyushu 807, Japan
}

\begin{abstract}
This article is an overview of the organization and activity of occupational health in Japan, focusing on part-time industrial physicians. The paper also deals with occupational health education, particularly for industrial physicians in the coming post-industrial society. Occupational health service rendered by part-time industrial physicians in Japan is unique in that the service is provided by the Japan Medical Association as well as by local medical associations under a comprehensive health care system and local communities. Postgraduate occupational health courses are also offered by these medical associations for part-time industrial physicians who practice primary care in the respective communities. The author of this paper proposes the establishment of an integrated science, "Industrial Ecological Sciences" to deal with changing features in occupational health in a postindustrial society. Industrial ecological sciences will include environmental science, human ecology, industrial safety, information sciences, medicoeconomics, health education, and industrial psychology. An institute of industrial ecological sciences, which is planned to be built at UOEH will not only conduct research but also act as a center for postgraduate education in occupational health in Japan. The organization and activity of occupational health service within the scheme of a comprehensive health care program may be worth investigation by other Asian countries. The Institute of Industrial Ecological Sceinces will become a center of occupational and environmental health education in Japan and, hopefully, for other Asian countries.
\end{abstract}

Key words: industrial physician, occupational health education, industrial ecological sciences, Japan Medical Association, occupational health service.

(Received 20 November 1981)

\section{Introduction}

The history and present status of occupational health in Japan was briefly summarized in English by Kubota (1980). The same author also presented a paper, "Occupational Health in Chemical Industries in Japan," at the 8th MEDICHEM subcommittee meeting of the PCIAOH in Tokyo, 1980. However, the actual practice, activities and training of occupational health professionals in Japan is not yet well documented in English. In this presentation I would like to introduce the unique organization, service, and activities of the occupational health program in Japan, focusing mainly on small industries or plants engaging part-time industrial physicians who also have a private practice in the communities, with the hope that a similar system may find acceptance in other Asian as well as 
other countries of the world. The education of part-time industrial physicians in occupational health in Japan will also be discussed. I will also discuss the postgraduate training program of the Institute of Industrial Ecological Science, which is going to be established at our university, which is called University of Occupational and Environmental Health, Japan, and will play a central role in the program.

Modern occupational health service in Japan was first established with the passage of the labor standard law in 1947. Over the first ten years emphasis was placed on the control of tuberculosis with great success. The decrease in mortality and number of patients with tuberculosis was so rapid that concerned people in other countries went so far as to describe it as "miraculous." Since about 1955, efforts to control occupational diseases, in particular, pneumoconiosis, heavy metal poisoning, and organic solvent poisoning, have been made by the enforcement of regulations and the establishment of occupational health services.

On the other hand, because of the rapid development of various industries, environmental pollution became a problem of great concern to the public. In recent years the larger industries have organized fairly good occupational health services including environmental protection engineering, but the smaller factories and plants could not afford such services, mainly because of difficulty in recruiting industrial physicians.

Appraising the situation, the Japan Medical Association started a postgraduate training program of occupational health for physicians engaged in private medical practice in local communities and willing to serve as part-time industrial physicians for industries, plants or factories located near their offices. The first course of lectures on occupational health for such physicians was given in Tokyo in 1965, with specialists invited to give lectures on occupational health. Since that time a director of occupational health has been appointed within the board of the Japan Medical Association as well as of the local medical association in each prefecture.

1. Organization of occupational health service under the comprehensive health care system of the Japan Medical Association

In Japan, there is the Japan Medical Association at the national level to which almost all physicians belong. Under the Japan Medical Association, there are 47 medical associations at the prefectural level (one for each prefecture), and further down the line, county and city medical associatons which are related to the prefectural medical association. Physicians belong to both the prefectural and local medical associations as well as the national medical association. In each medical association at the national, prefectural and local levels, there is a board of directors and the president of each association is elected directly or indirectly by the members." Among the board directors, one or two are appointed responsible for occupational health, except at the local level.

Fig. 1 shows the structure of the Japan Medical Association and its organizational relationships to the prefectural and local medical associations. The activities of the Japan 


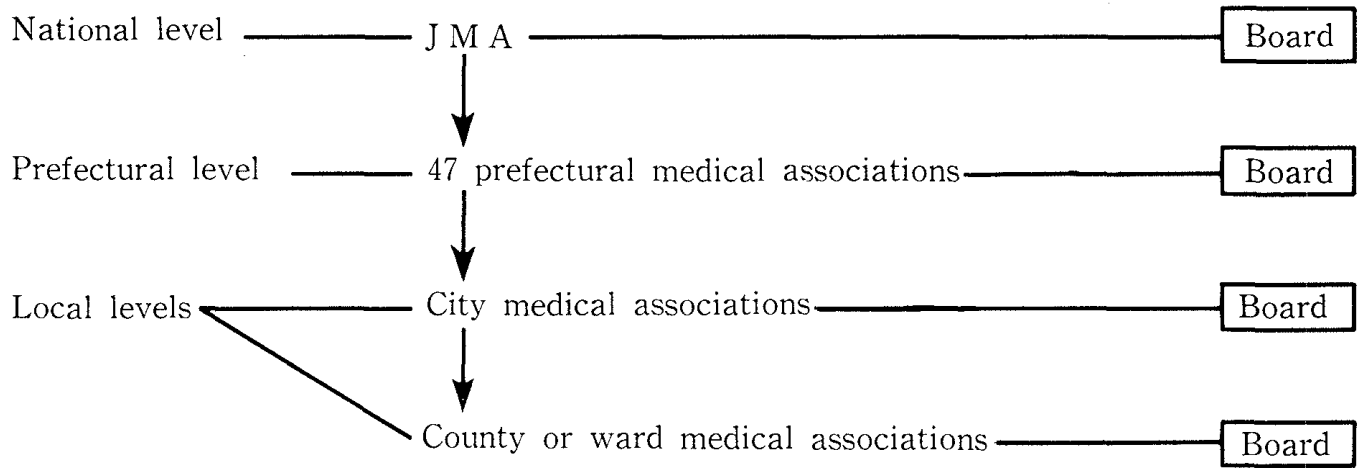

Fig. 1. Organization of Japan Medical Association (JMA). Among the board directors of JMA and each prefectural medical association, one or two are appointed responsible for occupational health.

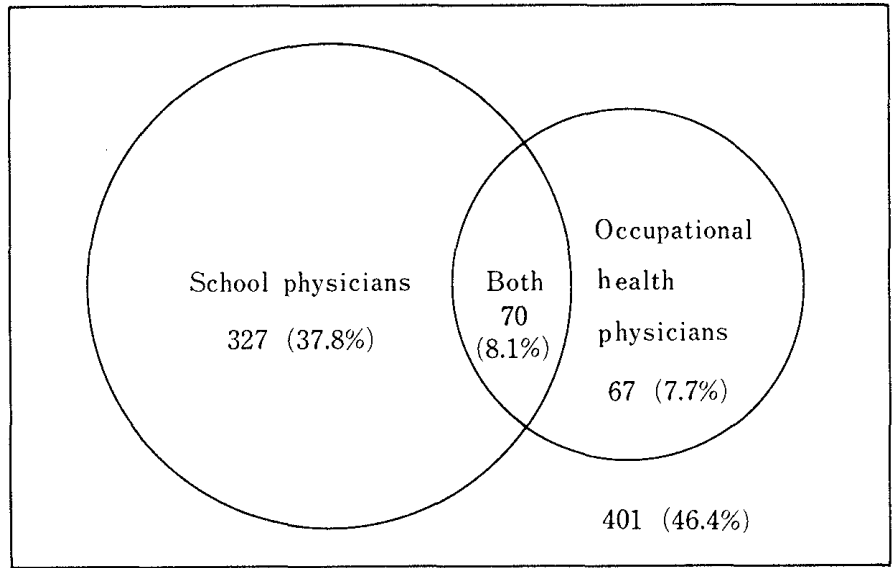

Fig. 2. School physicians and occupational health physicians (part-time). A total of 865 private practitioners in Kitakyushu City.

Medical Association including occupational health service are supported by the subordinate organizations. Thus, the occupational health program in Japan is included within the comprehensive health care system organized by the Japan Medical Association.

In the comprehensive health care program in Japan, school health service has a longer history than occupational health. However, recently much emphasis is being placed on occupational health. For instance, Fig. 2 shows the number of part-time school health physicians and industrial physicians in Kitakyushu, where our university is located. There is a total of 865 private practitioners in Kitakyushu with a population of about one million in 1980 . Of 865 , more than 400 , or almost $50 \%$, work as part-time school or industrial physicians, and of these, 70 in number, or $8.1 \%$ work for both school and industry. In terms of health care of the total life, it is good that a physician is able to observe the health condition of school children, industrial workers, and other members of the community to obtain a broad perspective on the health of individuals. 
The Japan Medical Association gives a three-day training course in occupational health twice a year and the physicians who attend this course are given a certificate by which they become eligible to be employed as part-time occupational physicians in a factory or factories. In addition to this course, there is also a national board examination for certification as "occupational health consultant." To pass this examination the candidates must study on their own. However, this examination is given by the Ministry of Labor without consultation with the Japan Medical Association or prefectural medical associations.

2. Organization of occupational health practice and activity in the prefectural medical associations

Each prefectural or local medical association organizes its own occupational health service according to the availability of occupational health resources and the specific organization of the community health care system. I will present one example in this paper. Himeji, which is located about 700 kilometers southwest of Tokyo, is a medium size city of approximately 500,000 population. The working population is about 200,000, more than half of which is employed in tertiary industries, about $45 \%$ in secondary industries, and $4 \%$ in primary industries. As shown in Fig. 3, in the Himeji City Medical Association, there is a health examination office, a working environment monitoring office, a medical association hospital, and a clinical laboratory (Himeji City Medical Association, 1981). Industrial physicians utilize these occupational health resources, maintaining close relations with the other organizations related to occupational health service such as the Himeji Office of Labor Standard Law, a local branch of the Ministry of Labor.

There are probably about 400 to 500 enterprises with more than 50 employees in Himeji. Industrial physicians are appointed by about 200 enterprises among them. More than $80 \%$ of these industrial physicians conduct preemployment and periodical health examinations as well as looking after the general health of workers. More than $90 \%$ of these physicians visit the factories once a month or once every two months. The city medical association holds refresher courses in occupational health three or four times a year. It is reported that 60 to 70 industrial physicians attend every course.

In 1979, specific health examinations for pneumoconiosis, health effects of organic solvents, lead, radioactive substances and other occupational hazards or diseases were performed on a total of about 4,000 workers of 160 enterprises by the industrial physicians of Himeji. Periodic health examinations were performed on about 45, 000 workers in the same year. A total of 800 measurements of working environments in 610 factories were performed in 1979.

The occupational health services performed by part-time industrial physicians and reported by the Occupational Health Promotion Foundation in 1981 are shown in Table 1. Although there are some differences in local community organization, similar services are provided throughout Japan. The occupational health program is thus completely 


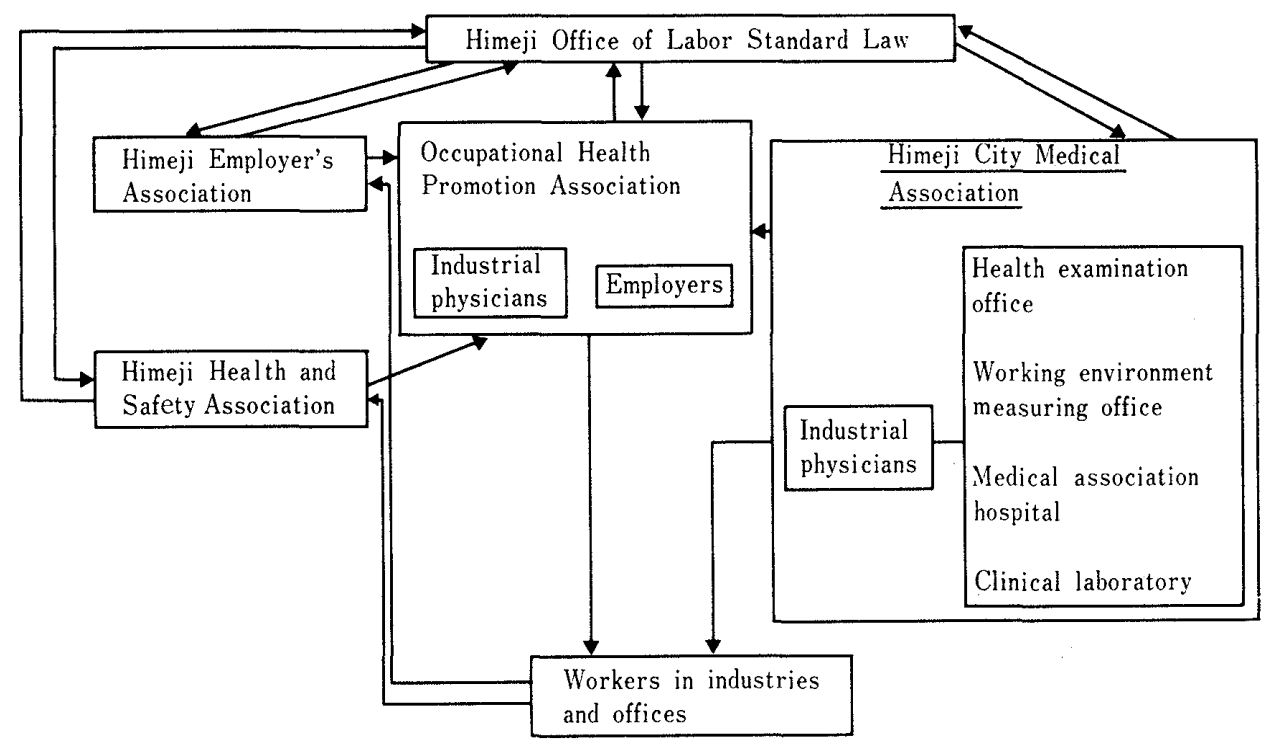

Fig. 3. Occupational health service in Himeji City.

Table 1. Activity of occupational health service by industrial physician - North Yokohama Area-

\begin{tabular}{lc}
\multicolumn{1}{c}{ Item } & Number of enterprises \\
\hline Health examination & 193 \\
Health guidance & 123 \\
Health education & 71 \\
Health consultant & 182 \\
Advice necessary to health promotion & 111 \\
Investigation of health hazard & 49 \\
Inspection of work place & 79 \\
Paticipation in health and safety committee & 36 \\
meeting & 42 \\
Investigation of absenteeism & 36 \\
Evaluation of measurements of working & 46 \\
environment & 112 \\
Recommendation to employer & $\ldots$ \\
First aid & 14 \\
Others & 1,094 \\
Not known & \\
\hline Total & \\
\hline
\end{tabular}

incorporated within the community health care system at the local level.

I believe that this type of occupational health service may be a good example which other Asian countries might care to investigate.

3. Postgraduate training courses prepared by the Japan Medical Association and prefectural medical associations

As mentioned above, the Japan Medical Association provides postgraduate training 
courses in occupational health twice a year in Tokyo, Fukuoka or Osaka. In 1981 the following lectures were given to an audience of about 300 in the course held in Fukuoka, Kyushu, over a period of three days. The titles of the lectures by specialists in each field are included in Tables 2,3 and 4.

At the prefectural level, each medical association provides postgraduate courses in occupational health for part-time industrial physicians in various factories and plants, usually lasting two or three days a year. The topics differ from prefecture to prefecture. For example, in Akita prefecture, which is far less industrialized compared to other prefectures, the subjects selected for the course held in January 1981 are shown in

Table 2. A. Appraisal and evaluation of health effects due to hazardous environment

1. Application of epidemiology to occupational health

2. Exposure to dust

3. Exposure to organic solvent

4. Threshold limit values of mutagenic substances and other hazardous chemicals

Table 3. B. Environmental control and health administration in work places

1. Evaluation of working environment --Evaluation of criteria for environmental measurements-

2. Practice of working environment control

3. Occupational health administration in work places -Control of working conditions--

4. Health checks of middle-aged and elderly people

Table 4. C. Recent trends in occupational health administration

1. Introduction to occupational health administration

2. On Code 35 of the amended labor standard law

3. Regulatory aspects in occupational health administration

4. Regulations relating to health control of workers

5. Regulations relating to the control of working environment

Table 5. An example of Postgraduate Course for Part-time Industrial Physicians (1981) - Under the auspice of Akita Medical Association-

1. Improvement of working environment

2. Health care of middle and high age workers -Called "silver health plan"-

3. Health care of workers exposed to heavy metals including lead, chromium and cadmium

4. Mental health care in the work place -Specifically for middle and high age workers- 


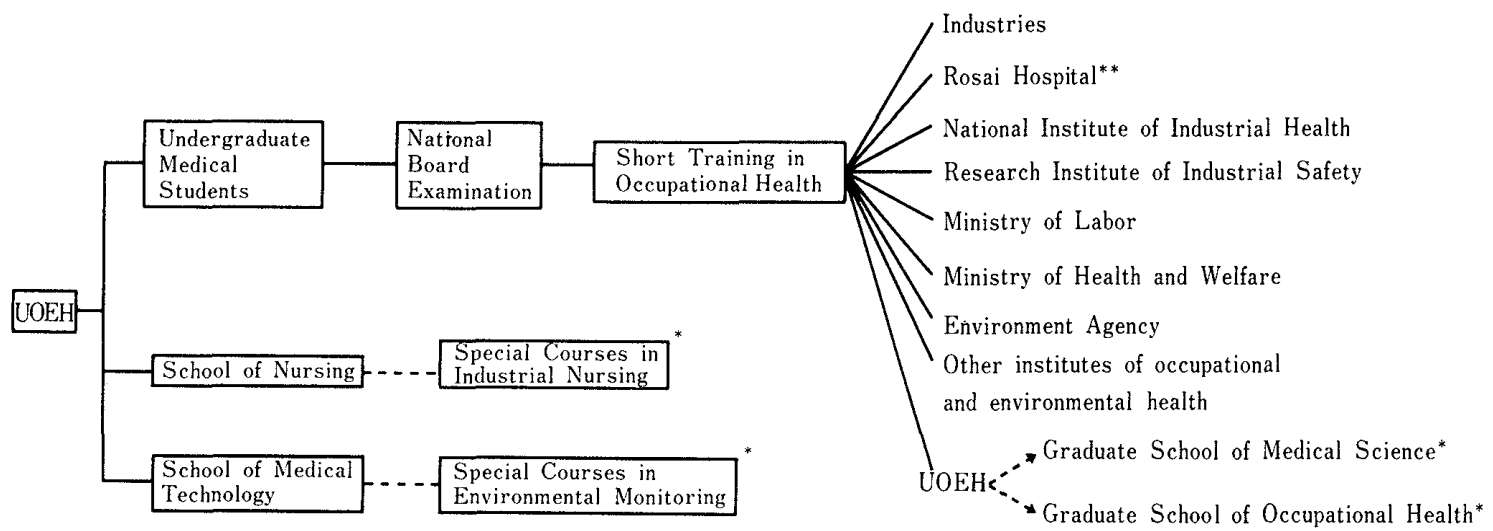

Fig. 4. Postgraduate training and occupational areas for graduates of UOEH.

*: In the planning stages.

**: Rosai Hospital: Workmen's compensation hospital or work injury hospital; Indirectly supported by Ministry of Labor. (One of them is exclusively for pneumoconiotic patients and others are more or less becoming "general hospitals".

Table 5.

In general those who attend are part-time industrial physicians. This type of postgraduate course is not compulsory, but the attendance is quite high, as many physicians are eager to obtain recent information on occupational health.

Since there are one or more medical schools in each prefecture, a director or directors of the prefectural medical association responsible for occupational health consult faculty members in selecting the subjects for the courses. The courses are paid for by the Japan Occupational Health Promotion Foundation.

From 1983, when the University of Occupational and Environmental Health, Japan, (referred to hereafter as $\mathrm{UOEH)} \mathrm{will} \mathrm{graduate} \mathrm{its} \mathrm{first} \mathrm{matriculants,} \mathrm{the} \mathrm{university} \mathrm{is}$ planning to give three-month postgraduate courses in occupational health at the university, not only for its own graduates but also for physicians graduating from other medical schools. This will be a more comprehensive course in occupational health, including training in air and water sampling techniques as well as laboratory techniques for measuring metals and other chemical substances in organic material. Most graduates of UOEH will work in industries as full-time industrial physicians and the postgraduate training program will vary according to individual needs (Fig. 4). After completing UOEH medical school and the postgraduate three-month course, some may, of course, choose to stay at the university to pursue an academic career.

4. Occupational health in the future

In the third follow-up committee meeting of the scientific session on "development and allocation of medical care resources" of the 29th World Medical Assembly in Tokyo held last August, I proposed the establishment of an integrated science, "industrial ecological 


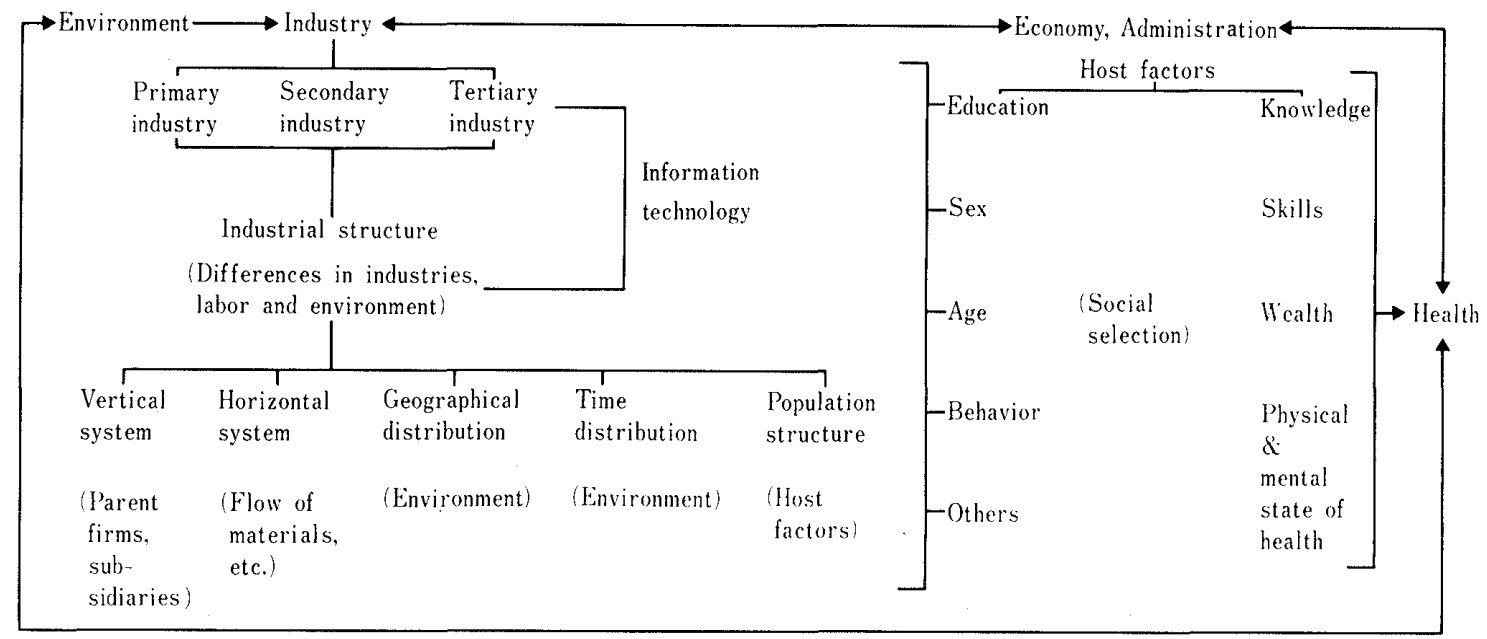

Fig. 5. Relationship between occupational and environmental system and health.

sciences," to deal with the changing features of occupational health. The relationship between the industrial ecological structure and human health is schematically drawn in Fig. 5 (Tsuchiya, 1981). As indicated in Fig. 5, the allocation and establishment of an industry can produce adverse or favorable effects on the natural and/or social environment of a community, including its economy and administration. The industry itself has complex structural relationships with other industries, primary, secondary, and tertiary, and each industry has its own structure in terms of work population, sex, age, education, etc. One industry may have a vertical relationship with other smaller industries, which have technological and economic affiliations with larger ones, i. e., "parent" industries. Other characteristics of the industrial structure may include horizontal relationships, geographical distribution, and time distribution. It is human beings who are the "hosts" of industries but each host has host factors, such as those shown in Fig. 5, and health and welfare is determined within the complex of the factors illustrated in Fig. 5. The purpose of industrial ecological sciences is to measure the relationships between these factors and health as well as general welfare, and to forecast the status of human health in the future, possibly as far as 20 years.

Under these conditions, the picture of disease has been changing very rapidly in recent years. This is characterized by an increase of chronic illnesses following the eradication of communicable diseases. However, this picture contains at present more elaborate and complex aspects of disease and health, which because of time I cannot explain in detail at this time. As shown in Fig. 6, the picture of disease has, of course, close relationships with other factors including industrial structures, and medical care resources are located between the industrial structures and medical care development. Medical care development further relates to the social environment, reflecting the picture of disease. As shown in Fig. 6, industrial ecological sciences aims mainly at studying the factors indicated by the bold lines. In the future $I$ want to place a particular emphasis on 
bioethics, which should be established as a new discipline in health care.

Keeping in mind expected changes in the total social and natural environment, industrial ecological sciences anticipates changes in industries through information obtained from industry and study of the problems accompanying changes and provides countermeasures. For instance, Table 6 indicates one aspect of industrial ecological sciences.

As seen in Table 7, one specialized field of medical science by itself cannot accomplish the purpose of the studies shown. In industrial ecological sciences at least two or three different fields of science join to perform a study on one subject. In order to establish industrial ecological sciences, UOEH is now performing cooperative projects in which a

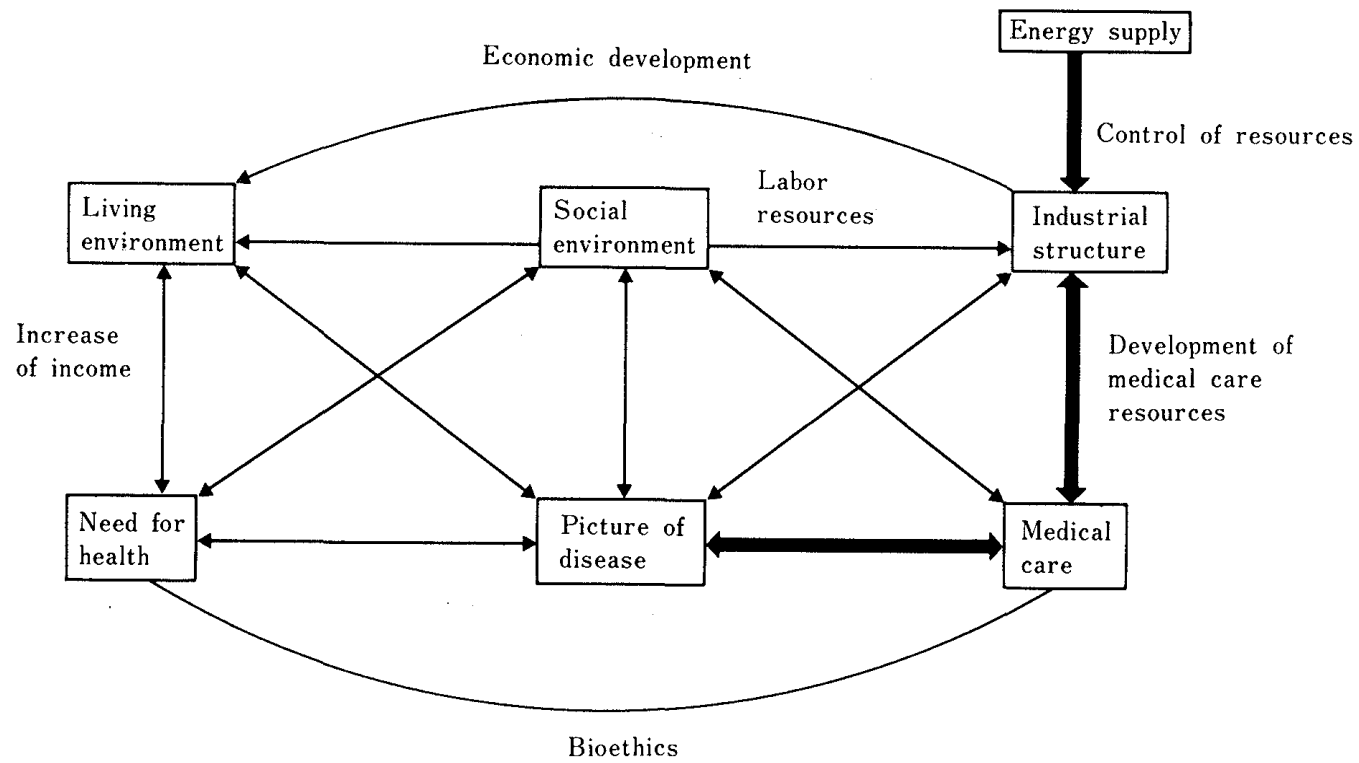

Fig. 6. Picture of disease and industrial structure.

Table 6. Industrial ecological sciences

\begin{tabular}{|c|c|c|c|}
\hline & Changes in industry & Some problems & Countermeasures \\
\hline 1. & $\begin{array}{l}\text { Development of new energy } \\
\text { sources (ocean, space, } \\
\text { natural phenomena) }\end{array}$ & $\begin{array}{l}\text { Special environment } \\
\text { (pressure, temperature) } \\
\text { Solitary work, other } \\
\text { problems }\end{array}$ & $\begin{array}{l}\text { Establishment of adaptation } \\
\text { theory, prediction of effects } \\
\text { on DNA by life science }\end{array}$ \\
\hline 2. & $\begin{array}{l}\text { Changes in biological, } \\
\text { chemical and physical } \\
\text { conditions in the ordinary } \\
\text { environment }\end{array}$ & $\begin{array}{l}\text { Increase in } \mathrm{CO}_{2} \text {, changes } \\
\text { in temperature }\end{array}$ & $\begin{array}{l}\text { Quantitative measurement of } \\
\text { pain, etc. } \\
\text { Biological significance of } \\
\text { change in enzyme }\end{array}$ \\
\hline 3. & New chemical substances & $\begin{array}{l}\text { Effects on human body } \\
\text { not known }\end{array}$ & $\begin{array}{l}\text { Establishment of methodology } \\
\text { of environmental assessment }\end{array}$ \\
\hline 4. & Automation & $\begin{array}{l}\text { Monotonous, solitary } \\
\text { work }\end{array}$ & $\begin{array}{l}\text { Establishment of occupational } \\
\text { mental hygiene }\end{array}$ \\
\hline 5. & $\begin{array}{l}\text { Changes in industrial } \\
\text { allocations }\end{array}$ & $\begin{array}{l}\text { Changes in urban and } \\
\text { rural environments }\end{array}$ & Setting up model cities \\
\hline 6. & Food & $\begin{array}{l}\text { Problems related to } \\
\text { population, food and } \\
\text { production }\end{array}$ & $\begin{array}{l}\text { Establishment of cost-benefit } \\
\text { theory }\end{array}$ \\
\hline
\end{tabular}


number of departments of the medical school, nursing school and school of clinical and environmental technology participate. Furthermore, the university is planning to establish an "Institute of Industrial Ecological Sciences," which will be composed of departments of environmental science, ecology, safety, information science, medicoeconomics, health education, and industrial psychology, as shown in Table 7.

Each department will include such subdivisions as shown in Figs. 7, 8, 9, 10,11 and 12. The institute will not only conduct research but also act as the core of postgraduate

Table 7. Institute of industrial ecological sciences

Departments

Occupational Hazard

Environmental Sciences

Safety Engineering

Health Education and Psychology

Sociology and Economics

Information Sciences

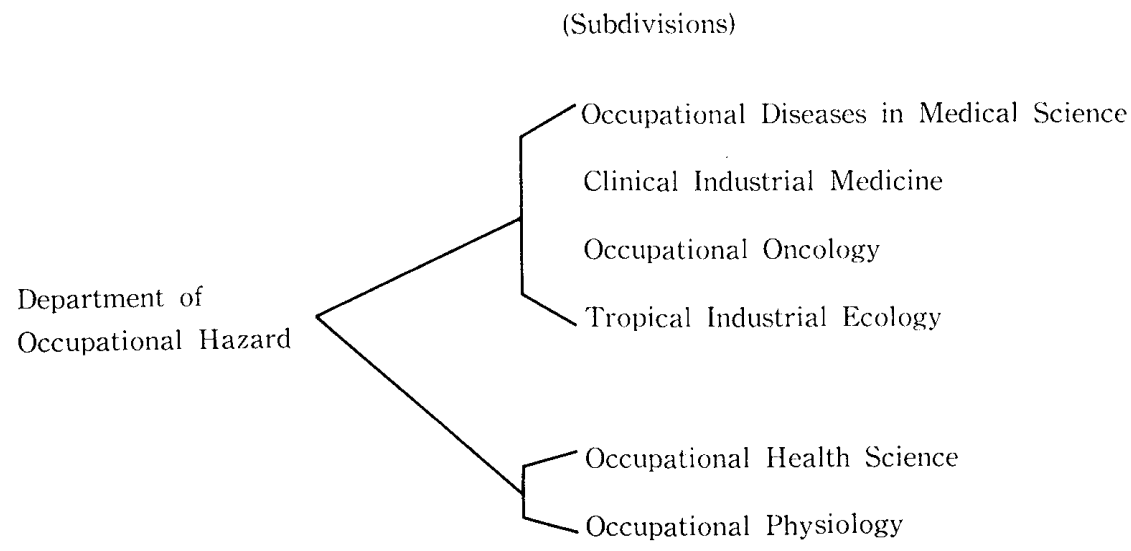

Fig. 7 .

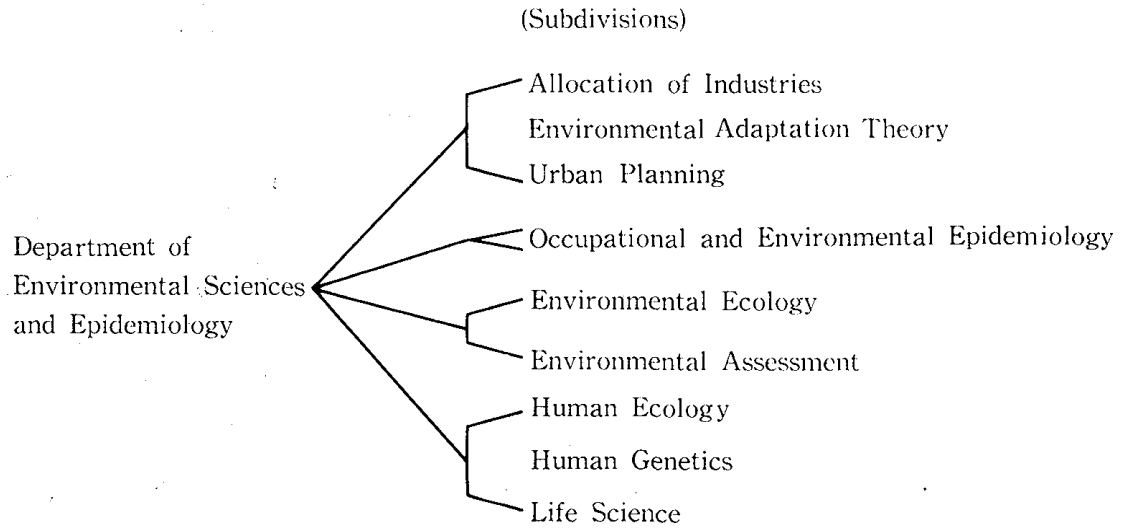

Fig. 8. 


\section{(Subdivisions)}

Department of
Safety Engineering $\left[\begin{array}{l}\text { Accident Theory } \\ \text { Industrial Management } \\ \text { Health Engineering } \\ \text { Safety Engineering } \\ \text { Social Engineering }\end{array}\right.$

Fig. 9.

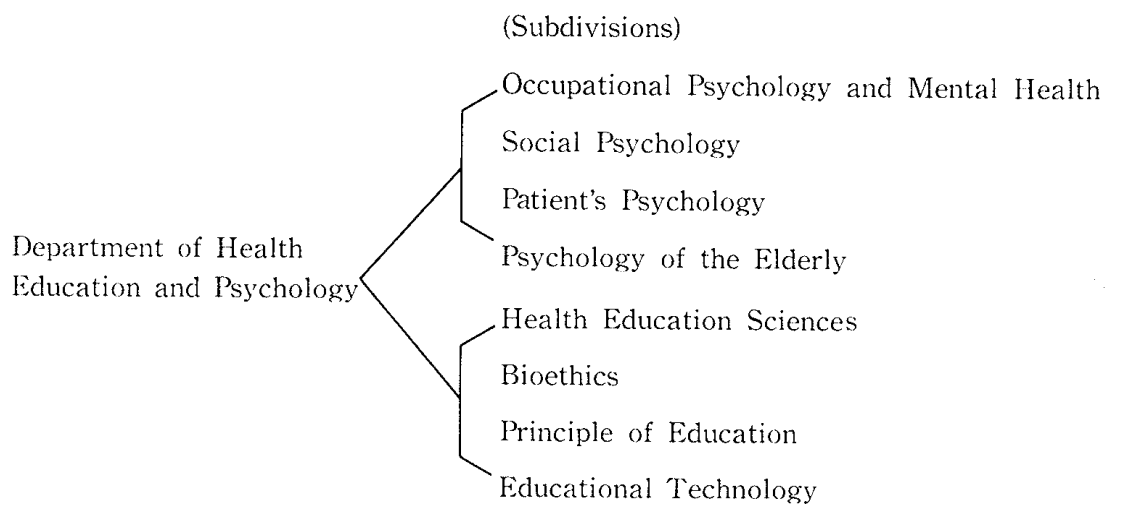

Fig. 10 .

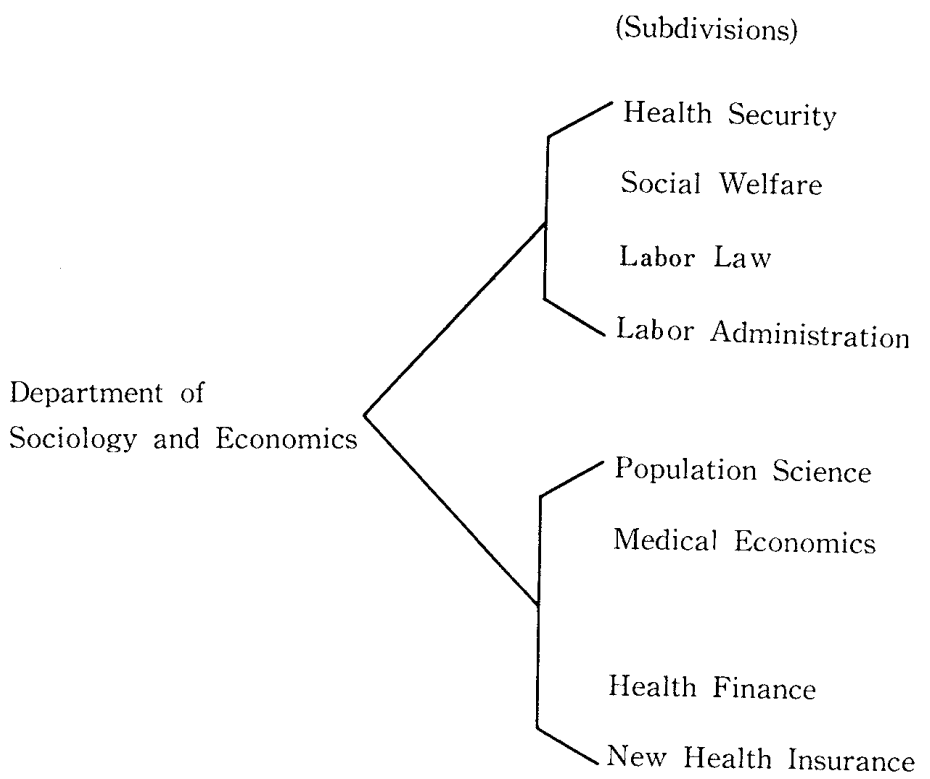

Fig. 11. 


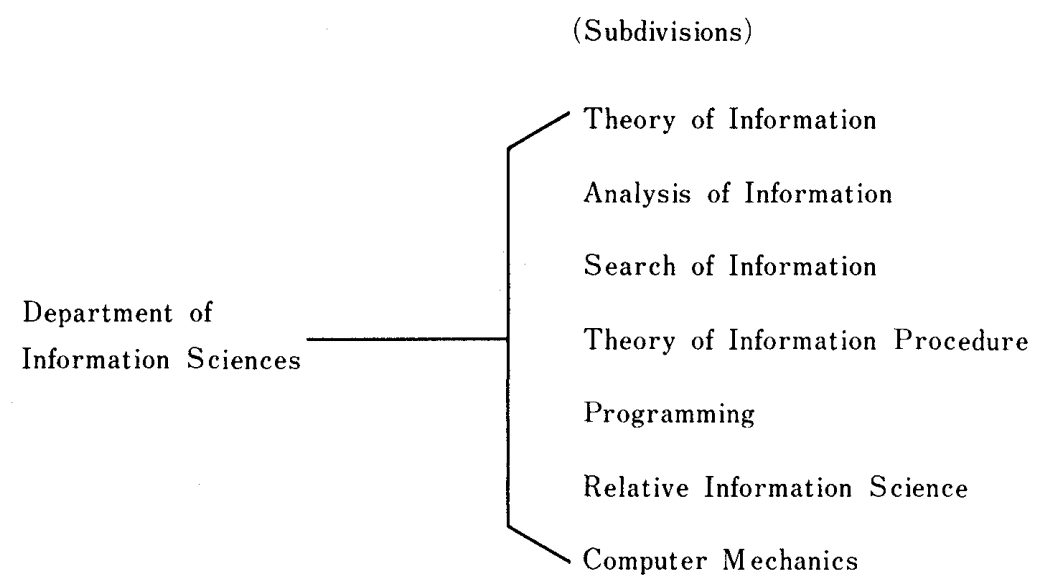

Fig. 12.

education in occupational health in Japan, and will hopefully be able to provide occupational health education for other Asian countries as well.

I believe that industrial physicians in the future should have sufficient knowledge and techniques in the related sciences mentioned above; otherwise occupational health in the future will not be able to solve the problems which will become more and more complex with the passage of time.

\section{Summary}

In this short presentation I have outlined the organization and activity of occupational health service in the comprehensive health care program provided by the Japan Medical Association and subordinate medical associations. This system may be worth investigation by other Asian countries. Postgraduate or refresher courses provided by the Japan Medical Association and a prefectural medical association are introduced as examples.

In the future, occupational health will have to deal with a more and more complex and changing human environment. In order to meet the problems of the future I propose a new integrated science, "industrial ecological sciences," to form the basis of occupational health. Finally, the University of Occupational and Environmental Health, Japan, is planning to establish an Institute of Industrial Ecological Sciences, which the author hopes will become a center of occupational and environmental health education for Japan and other Asian countries.

This lecture was presented at the 20th International Congress on Occupational Health as an invited lecture, held in Cairo on September 28, 1981.

\section{References}

Himeji City Medical Association (1981): Himeji City Medical Association Report. p. 172. 
Kubota, J. (1980): Occupational Health in Japan-An Overview-. Asian Med. J., 23: 308-318.

Occupational Health Promotion Foundation (1981): Investigation on Part-time Industrial Physicians. 36 pp.

Tsuchiya, K. (1981): Industrial Ecological Sciences-An Approach from Medicoeconomics-. WMA Follow-up Committee on Development and Allocation of Medical Care Resources. July 30,31August 1, 1981, Tokyo.

日本に打ける産業保健サービスの特徵

第20回 国際労働衛生学会 招待講演

上屋 健三郎

産業医科大学 学辰

要旨：本論文は日本における産業医活動，特に嘱託産業医活動の特徵を紹介し，医師会における 生涯教育の内容に触れ，更に将来の産業保健についての提案を行った総説論文である.我 が国における嘱託産業医の組織並びに活動は，日本医師会のリーダーシップのもとに，総 括地域医療の一端として行われているとてろに特徴があり, 他のアジア諸国においても参 考となる幾つかの側面を有している．特に最近では県医師会並びに市医師会に扔ける生涯 教育，產業保健の地域レベルでの組織には注目すべきものがある．20年後の社会環境の変 化に適応した産業保健については，いわゆるポストインダストリアルソサエティの社会環 境に適した体制が必要であり，との為に本論文においては「産業生態科学」という，ある 意味での総合科学を提唱し，その研究を基本に産業医学の生涯教育が行われる心゙きである と述べている。

J. UOEH（産業医大誌），4（1)：51-63（1982） 